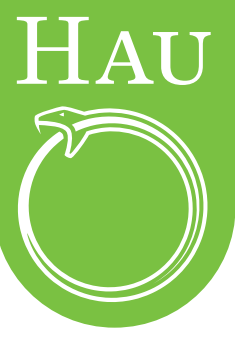

\title{
Horizontal and vertical relations
}

\section{Interrogating "in/dividualism” among Christian Bidayuhs}

\author{
Liana CHuA, Brunel University London
}

This article addresses aspects of the dividual/individualist debate by thinking through an analogous set of ideas and practices among the Bidayuh, an indigenous group of Malaysian Borneo. When Bidayuhs began converting to Christianity in the 1950s, some missionaries contrasted their communal way of life with the "individualism" of the new religion. Drawing on contemporaneous ethnography and my own research, I sketch a more complex picture, showing how both pre-Christian and Christian sociality have been shaped by the shifting intersection of "in/dividual" impulses that derive from the "horizontal" and "vertical" relations in which persons are enmeshed. Tracing the trajectories of these impulses and relations from life to death and beyond, this article attempts to detach questions of in/ dividualism from personhood, while arguing for the need to take seriously the variegations and affinities between different strains of Christianity and Western and non-Western socialities.

Keywords: Christianity, Bidayuh, Sarawak (Malaysian Borneo), in/dividualism, morality, personhood, death, ritual

In 1969, a British missionary stationed at the Bidayuh village where I now work wrote an article about Christianity's lack of progress among the local denizens. Evidently frustrated, he reflected,

The missionary must be patient. The Dayak people [as Bidayuhs were then known], whose traditional abode is the long-house, have a way of life, and a system of taboos which have held them together over the centuries. But, granted that there is no point in rushing in there and disrupting their traditional way of life without leaving them with a sound 
understanding of Christianity, one has to begin somewhere, and that can only be by creating individual Christians. These, one hopes, will become the leaven of the whole lump. (Sidaway 1969:143-44)

David Sidaway's comments were more pragmatic than ideological, reflecting the fact that most early Bidayuh converts were indeed single persons or families. ${ }^{1}$ However, they also echoed the contemporaneous musings of many missionaries and scholars, who saw Christianity as introducing new individualist sensibilities to a society governed by profoundly communal conventions. In a British Colonial Office survey, for example, Edmund Leach noted that some Bidayuhs who had been "in close contact with Christian and other sophisticating influences ... have begun to abandon the longhouse organization, in preference for individual dwellings" (1950: 67). A decade later, the Anglican archdeacon Peter Howes contrasted his Bidayuh acquaintances' way of life, in which "work" and "worship" were intertwined, with how, "in the Christian community, every man tends to become his own 'Priest" (1960: 494).

These remarks, fleeting and candid, were subsumed amid lengthier expositions on ritual, sociality, and economic change in Bidayuh villages. However, their existence reminds us that questions of in/dividualism (by any other name) are not the sole preserve of contemporary anthropology but have long been topics of concern in the real world. Like the contributors to this special section, Sidaway, Leach, and Howes were wrestling with the notion-widely held both within and beyond academe-of Christianity as a distinctively individualizing force and problematizing its manifestations in the native societies where it took root. Yet, as I shall suggest, the contrast that they drew between (Western) individualism and (Bidayuh) communalism was not quite so clear-cut.

Drawing on my own research and the writings of William Geddes, an anthropologist who worked in the area in the 1940s and 1950s, this article explores how Bidayuh models of personhood, sociality, and morality have been construed and transformed both historically and across individual lifespans. I suggest that Bidayuh persons were and are understood to be shaped by a combination of what we might (analogically) call "dividual" and "individual" impulses. Deriving from the different relations that shape daily life, these coexist in shifting permutations within and beyond persons, only coming apart when they die. Focusing on two overlapping contexts-moral personhood and postmortem rituals-I shall trace their trajectories from life to death and beyond.

The key aim of my ethnography is to demonstrate the usefulness of a processual approach to questions of in/dividualism, debates around which have recently enlivened the anthropology of Christianity. In the last few years, a number of scholars (e.g., Daswani 2011; Mosko 2010; Vilaça 2011; Werbner 2011) have sought to reassess the nature of Christian personhood by drawing on theories of dividualism originally conceived in South Asianist and Melanesianist ethnography (see below). By demonstrating how conversion to Christianity can produce myriad forms of personhood and reflexive, ethical subjects rather than mere clones of "Western individuals," they have helped to destabilize the long-standing dichotomy-originally

1. For details of Christian conversion in Bidayuh areas, see Chua 2012. 
elaborated by Marcel Mauss (1985 [1938]) and since perpetuated by many anthropologists-between the "person" as a relational, socio-culturally constituted (nonWestern) entity and the "self" as a reflexive, individualized product of a peculiarly Western history and Christian theology. My objectives in this article overlap with theirs in that respect. But rather than using notions of in/dividualism to illuminate anthropological conceptions of personhood, my aim here is actually to unmoor the two-to explore what I call in/dividualist impulses beyond the confines of personhood. Such an approach, I suggest, does not only dissolve the (fundamentally Maussian) contrast that anthropologists have habitually drawn between Western (=Christian) individualism and non-Western dividualism or "relationality" (Busby 1997: 261), but also raises questions of how personhood can be conceived less as an entity than as a complex and sometimes contradictory process that unfolds on multiple scales and temporalities.

These arguments will be fleshed out over the course of the article. We begin, however, with an introduction to Bidayuh society and what was effectively a contemporaneous rejoinder to mid-twentieth-century missionary accounts: Geddes' discussion of a particular form of Bidayuh individualism.

\section{"A society of democrats"?}

Constituting Sarawak's second-largest indigenous group, the Bidayuh (formerly called "Land Dayaks") have historically lived in longhouse-based, rice-planting villages in the hills around the state capital Kuching. Their relative accessibility made them among the earliest communities to encounter Christianity, with Anglican missionaries first setting up clinics and schools in the area in the mid-nineteenth century. However, it was only in the 1960s and 1970s that Anglicanism and Catholicism - followed by several smaller denominations, including Methodism, Seventh-Day Adventism, and the nondenominational SIB (Sidang Injil Borneo/ Borneo Evangelical Church)_began making inroads into Bidayuh villages.

A key reason for this, as Howes (1960) discovered, was the tight entanglement of "work" and "worship" in Bidayuh life. Until the late-twentieth century, most Bidayuhs followed adat gawai, a ritual complex structured around rice cultivation and relations with spirits, ancestors, and other nonhuman entities. Governed by numerous omens, prescriptions, and proscriptions, gawai shaped and was shaped by the rhythms of the agricultural cycle and daily sociality, binding the inhabitants of every village in multiple webs of obligation and responsibility. This close alignment of ritual, sociality, and livelihood made it difficult for Christianity to dislodge gawai from its central position in Bidayuh life, and it was only from the 1960s, when many young people took up waged labor in urban areas, that the link between work and worship began to be severed.

On the surface, then, pre-Christian Bidayuh society appeared to be an archetypal community in which individuals were seamlessly integrated into a cohesive, self-regulating whole. As we shall later see, there is some truth to this vision. To muddy the picture, however, I now turn to the work of William Geddes, who lived in the village of Mentu Tapuh between 1949 and 1951. Conducted as a follow-up to Leach's survey, Geddes' fieldwork spawned a lengthy report (1954) and popular 
narrative (1957) that remain the most vivid, comprehensive ethnographies of any one Bidayuh settlement to date. My interest here, however, is in Geddes' characteristically sensitive attempt to tease out the complex relation between what he depicted as individualism and communalism in his field site.

Like Sidaway, Leach, and Howes, Geddes noted the common interests, concerns, and possessions that united Land Dayak villages, the "sentimental" ties shared by their inhabitants and the "positive value" that they assigned to the notion of community (1954: 20). However, he had no illusions as to what drove this society, describing a Land Dayak village as

a community held together in the first place by a web of sentimental ties developed by and through family connections and by other associations for specific ends. The strands of the web are constantly changing and what gives an individual member of the community his importance and opportunities is not so much any particular strands as the number and range of those linking other persons with him. The community is of value to all its members because of what it gives them. It is a social club, a land league, a reservoir of labour, a defensive alliance, and something of a Church. It is a society of democrats, self-ruling, with some of the vices of anarchy and the virtues of an absence of rank or class. (Geddes 1954: 33)

For Geddes, "the Land Dayaks certainly do not live in one of those societies where individuality is sunk in the affairs of the tribe" (1957: 20). Rather, he argued that "inherent in the whole form of society" (34) was a "sometimes extreme individualism" (20) that had the effect of fostering communal cooperation and cohesion.

To illustrate, Geddes took apart what many observers saw as the emblem of collective Bidayuh sociality: the longhouse. Despite engendering an impression of uniformity and cohesiveness, he said, the longhouse was "not a communal building at all, but in reality a series of homes all joined together" (1957: 29). Nearly every component was owned and maintained by individual households, the core units of village organization. This combination of shared space and individual autonomy, he argued, cultivated peculiar forms of collaboration and exchange. Groups of households frequently built their apartments at the same time to exploit reciprocal labor arrangements and shared raw materials (1954: 34), and individuals kept their outer verandas in good condition on the basis that they were using their neighbors' verandas as much as their neighbors used theirs (1954: 30). Such activities, argued Geddes, reflected the fact that "in practical affairs the people work in better with one another, but they do so from mutual interest and not because they are bound to a system or to rulers" (1957: 21).

The flip side of this meant that different parts of the longhouse were left in varying states of (dis)repair, depending on how well they were maintained by individual households. Communally used facilities such as tracks and bridges were neglected, making villages look "as though a flood has swept through them, with the piles of the longhouses rising gaunt from the surrounding debris of broken coconuts, dead palm fronds, refuse, and rotting bamboo" (Geddes 1954: 34). Geddes' informants saw little point in expending their own labor on cleaning and maintaining amenities that everyone else would use-nor would they impel others to do so. A similar, scaled-down principle of individual autonomy was discernible in village 
politics, with Geddes describing his acquaintances as "anarchists to the extent that no one amongst them is strong enough to force the others to do anything which they do not wish to do" (1957: 21). Village leaders were primarily mediators and representatives, and meetings were forums at which opinions were aired and allround agreement (though not unanimity of opinion) was sought (22-23). But just as households' participation in longhouse maintenance was shaped by the expediency of collective action, individual participation in village life was influenced by "the greatest force controlling persons' actions in this society ... public opinion" (23). As Geddes put it, "the Dayak democrats do not bow to it lightly, but they do not enjoy conflict with it, and the greater the conflict the less happy they are" (23). Accordingly,

The public debates not only argue out a common decision but they also let each person see just how strong is the support for it, and therefore how much disapproval he must face if he privately decides to do otherwise. (Geddes 1957: 23)

With its apparent reliance on an "ontologically privileged, transhistorical and transcultural" (LiPuma 1998: 56) notion of the individual, Geddes' ethnography may appear hopelessly irrelevant to this special section on personhood. But its usefulness, I suggest, lies less in its analytical units than its analytical slant. Rather than pitting "the individual" against "the community," Geddes revealed the complex, mutually constitutive dynamic between the two in ideology and practice. Crucially, he separated ideals, motivations, and effects, showing how ostensibly communal activities and sentiments were often offshoots of what he depicted as a peculiarly Bidayuh form of individualism. Such a move made it impossible to treat "society" as a (Durkheimian) meta-agent-as the missionaries arguably did-by revealing how the Bidayuh community was little more than the sum of its parts. Concomitantly, it suggested how Bidayuh persons could be viewed as both autonomous and relational: as constantly juggling two different but not incommensurate sets of values or ideals (individualism and communalism) in day-to-day sociality.

Geddes' portrait of Bidayuh individualism is germane here as a means of complicating the terms of the in/dividualism debates that have periodically flared within anthropology since the 1980s. The in/dividual question first acquired broad anthropological prominence through Marilyn Strathern's The gender of the gift (1988). Riffing on McKim Marriott's earlier portrayal of South Asian persons as "dividuals" composed of "heterogeneous material influences" or "coded substances" that could be absorbed and transferred (1976: 111), Strathern heuristically contrasted ideal models of "Western individualism" and "Melanesian dividualism" in a powerful critique of anthropological assumptions about gender, personhood, and sociality. Like Marriott and indeed many other ethnographies of personhood (Bloch 2011), Strathern treated the "dividual" as an analytical foil to Euro-American understandings of the "individual" as a bounded, indivisible unit distinct from "society" and "social relations" (1988: 12-13). Unlike "individuals," she suggests, "dividuals" may be seen as "the plural and composite site of the relationships that produced them" (1988: 13). In this respect, they are "partible" entities (1988: 185) from which relations can be detached and attached to others (and vice versa). Within this "Melanesian theory of social action" (174), persons are able to elicit capacities and 
substances from each other, potentially enacting transformations in both parties. Here, "identity is an outcome of interaction" (127-28), not the other way around.

Strathern's discussion centered on the topic of gender, which she portrayed in the Melanesian context as the momentary outcome and form of social relations rather than a fixed attribute of personhood. The book's wider legacy, however, was to thrust the theme of personhood under the analytical spotlight by unveiling the contingency of the Euro-American model of the "individual" and questioning its universal applicability. Since then, the in/dividual and its cognates have remained cornerstones of anthropological debates about personhood in Melanesia and elsewhere (e.g., Busby 1997; Daswani 2011; Lambek and Strathern 1998; Vilaça 2011; Werbner 2011). Most recently it was revived by Mark Mosko's reworking of "New Melanesian Ethnography" (2010), in which he argued that "the total Christian person" - that quintessentially Western individual - could in fact be understood as "as fully partible as indigenous Melanesians” (2010: 219). Working from this premise, Mosko undertook a controversial rereading of several influential ethnographies of Melanesian religion, concluding that Melanesians' engagements with Christianity were not—as they had been portrayed—ruptures or syncretistic fusions (2010:231) but "the conversion of one dividualist form of personhood, agency, and sociality into another" (2010: 232). The heated debate that Mosko's essay provoked-and the question of whether he had overgeneralized the concept of "dividualism" into meaninglessness (Robbins 2010: 242; see also Introduction)-continues to rage today.

The current special section may thus be seen as another intervention in this long-running anthropological discussion about the nature, limits, and crosscultural specificities of personhood. What I would like to do in this article, however, is take a different path and adopt an analytical strategy inspired by Geddes' ethnography. Rather than starting with a notion of in/dividuals as different modes of personhood, I shall attempt to trace the trajectories and conjunctures (or lack thereof) of in/dividualist impulses as they coexist within or transcend Bidayuh persons. In keeping with Strathern's heuristic spirit, my aim here is to open up new dimensions of the in/dividualist debate while considering the analytical mileage of extending it beyond the bounds of personhood and exchange into different thematic realms. But first, some ethnographic groundwork.

\section{Daneh's story: Moral personhood in contemporary Bidayuh society}

Since the mid-twentieth century, Bidayuh villages have undergone numerous farreaching changes. Rice-planting has largely been displaced by waged labor, and many villages-now consisting mainly of detached houses-have become part of the Kuching commuter belt. The vast majority of the population has adopted Christianity since the 1970s, although diminishing handfuls of adat gawai practitioners still remain. My adoptive village contains three different congregationsAnglican, Catholic, and the smaller and newer SIB — and, up to 2011, a small group of elderly gawai followers. As I explain elsewhere (Chua 2012), the new religion has suffused Bidayuh sociality, politics, and morality, so much so that being Bidayuh is now seen as tantamount to being Christian. All these changes have not only laid 
bare but also profoundly transformed my acquaintances' models of sociality, personhood, and morality, as I shall now illustrate through the story of the man with the "spinning" head.

"Daneh" was a villager in his mid-thirties who spent his days wandering about in a drunken stupor, usually in search of food and company. Unmarried and childless, he lived off his relatives and was mostly indulged by the other villagers, who disapproved of his lifestyle but saw him as relatively harmless. Occasionally, however, Daneh would engage in unacceptable behavior, such as physically harassing people and once trying to break into my house while I was alone late at night. At these points, the full force of collective fury would rain down upon him. Following his attempted break-in, for example, I was told by the leaders of the Catholic chapel, to which he belonged, that they had severely chided him for disturbing the peace ("What will people think of you?" they asked him) and giving the village a bad name ("Who knows what you might write about us?" they said to me).

Although this pattern of chastisement played out many times during Daneh's life, the villagers never condemned him as inherently or unchangingly "bad" (arap): the alcohol made his "head spin" (bak kaning), they said, leaving him less able to feel mangǔh (shame) or know adat (customary law; the way of the world). While they could chide and chivvy, they would not go further, reasoning that Daneh's deeds and decisions were his alone. One day, he was found dead from presumed alcohol poisoning in a jungle clearing off the main road, and buried with the usual Catholic rites. When I next returned to the village, I tried using his demise to trigger some discussions about soteriology and morality. But beyond rehearsing the facts about when and where he was found, my acquaintances refused to speculate about his character or whether he'd gone to heaven or hell, tending instead to express their sympathy for his relatives. No, he didn't attend Sunday prayers or really "follow" (tundak) Christianity, they said, but ultimately, only God knew what would become of him.

Although I never discussed moral or religious issues with Daneh during our brief, semicoherent interactions, I suggest that the other villagers' responses to him offer a glimpse into the push and pull of the different impulses and relations that constitute moral personhood in Bidayuh society. First, the collective excoriation routinely provoked by Daneh's transgressions reveals the enduring importance of what Geddes called "public opinion" in social life. Like the Iban, Bidayuhs historically lack hereditary hierarchies, leadership categories, and formal mechanisms through which to enforce political decisions, obligations, and sanctions-a tendency that Leach (1950:71) and others characterized as "egalitarian." ${ }^{2}$ As Geddes found, this made the (notional and actual) community at large the most persuasive and effective arbiter of individual behavior. Although Bidayuhs are today subject to the Malaysian system of village administration and law enforcement, the question of "what everyone else will think" remains a critical concern in their moral decisions. This relational awareness is best encapsulated by the concept of mangǔh, roughly translatable as "shame." Essentially "the felt pressure of convention upon the individual person" (Geddes 1954: 54), mangǔh is described by my acquaintances as an

2. For a recent overview of similarly "egalitarian" models across Southeast Asia, see Gibson and Sillander 2011. 
unpleasant feeling; the sense that others are watching and speaking unfavorably of them. It is this feeling, for instance, that deters couples from getting divorced in case they become the subject of gossip, and that parents arouse when scolding children. "Are you not mangǔh?"-which Daneh heard quite often-is one of the sternest rebukes in the village that individuals quickly learn to avoid.

Mangǔh, then, is a relational sensation elicited primarily through the words and gazes of others. As such, it is a prominent manifestation of what I call the "horizontal" relations that shape day-to-day village sociality. By this, I do not mean that people who engage in such relations are (or are seen as) equals in age, achievement, or rank, or indeed that all village relationships are "horizontal" in nature. Rather, I use the term to capture the sense, shared by most village residents and often extended to the many non-Bidayuhs with whom they interact, of being enmeshed in a web of basic responsibilities and obligations that apply equally to everyone regardless of their status, thus making them peers in a specific moral context. These include, for example, ensuring that no gift, arrear, or favor is left outstanding, cultivating and maintaining relations through commensality, and engaging in reciprocal labor exchanges. Such relations are governed by the pervasive understanding that individual persons live best in an ideal, cohesive, peaceful community (kaum) in which everyone is "the same" (sama) $)^{3}$-or more specifically, in which nobody stands out as radically different or (dis)advantaged, whether through wealth, power, or drunk and disorderly behavior. Both Christians and non-Christians describe this ideal state of equilibrium as one of "coolness" ( madud), which they contrast with the "heat" (păras) caused by conflict, illness, indebtedness, and other disruptive elements.

Such horizontal relations do not constitute moral peers that are identical to Strathern's partible dividuals. However, they do generate certain understandings and impulses that can be classified as dividualistic in Strathern's sense. Chief among these is the acknowledged capacity of persons to evince and enact moral transformations in others, not only through the exchange of substances and artifacts (see Chua 2009) but also through constant reminders of their joint enrolment in an ideal kaum. The effect of this is to render persons literally and emotionally "vulnerab[le] to interaction," as Ward Keeler defines isin, the Javanese version of mangǔh (1987: 66). In this framework, persons are not quite partible, but they are always potentially transformable through the relations-often objectified in different forms, such as gifts, food, and thoughts-that they share with others. Such relationally enacted transformations are constitutive of persons' social form or identity-as siblings, land owners, village members, and so on-at any one point, depending on the particular configuration of relations at play (Strathern 1988: 176). Daneh may have been a son, brother, occasional worker, and household member, but in those moments of rebuke, he was very much constituted and expected to behave as a village resident.

On one level, then, the other villagers were exhorting Daneh to act as a good member of the community by appealing to his dividual sensibilities and capacity

3. This does not mean that Bidayuh society is completely undifferentiated in reality. As Clifford Sather (1996) also observes among the Iban, what shapes people's choices and judgments is an ideology of equality. 
to feel mangǔh. In so doing, they exercised what they saw as their own horizontal moral responsibility to him and the wider community. But as the involvement of the church leaders suggests, my acquaintances were also engaging with Daneh through a specifically Christian framework that emphasizes "loving one's neighbor" and doing good things in the world. As I explain elsewhere (Chua 2012), the emergence of this community-centered framework can be partially traced to the conversion strategies deployed by many mid-twentieth-century missionaries. Recognizing the positive connotations of the idea of community for their nascent flock, the Anglican and Catholic missions developed vernacular catechisms and rituals that elaborated and sacralized existing notions of communal well-being and coolness. For example, converts were often depicted as part of "one household in Jesus" (ndi rawang darum Jesus) - the household being the base unit of commensality, ownership, and obligation in Bidayuh villages - and encouraged to eat together and care for each other as a basic religious responsibility. By fostering these new "horizontal" bonds and practices, Christianity thus enshrined communal well-being as an explicit end in itself. At the same time, it amplified and multiplied the dividual forces that tugged at persons, giving them another possible social form in which to appear: as members of a new Christian community.

This does not imply, however, that Bidayuh society fundamentally consists of dividuals or-as some anthropologists have argued elsewhere (e.g., Vilaça 2011; Werbner 2011) - that Christianity itself has created new kinds of dividuals. As Daneh's story reveals, the force of horizontal relations and dividual tendencies can be offset by a strong awareness of persons' individual moral autonomy-the basis, I suspect, of Geddes' understanding of Bidayuh individualism. Such moral autonomy is sometimes portrayed by my acquaintances as a property of the simangi (soul), a pre-Christian concept endemic to much of maritime Southeast Asia that has also been incorporated into Bidayuh Christianity (Chua 2012: 70-71). Simangi is the indivisible, animating core of persons and the source of their consciousness and cognizance, without which (as my adoptive grandmother put it) we would sit there staring into space with wide-open eyes and mouths. The simangi may be influenced by the things and relations that make up a person, but at the end of the day, it is still regarded as the sole source of a person's moral agency. Daneh's judgment may thus have been alcoholically impaired but he was nevertheless seen as an autonomous moral agent responsible for his own choices and actions. The other villagers could try to influence him by playing on their horizontal bonds with him but would never coerce him into anything; indeed they would have fiercely defended his right to behave as he wished up to his death.

If a model of Bidayuh personhood were to be drawn, then, it would consist of two distinct, though not unconnected, components: an autonomous, indivisible moral core and an ever-shifting, permeable tangle of relations around it. The first, with its emphasis on autonomy and specificity, may be said to give rise to individual tendencies, and the second, to dividual ones-that sense of being physically, socially, and emotionally invested in and responsible to one's moral peers. Neither a clear-cut dividual or individual, the person must thus engage in a constant process of navigation and negotiation between such in/dividualist impulses and motivations. In recent decades, however, this implicit model of personhood and sociality in day-to-day village interactions has been complicated by various 
religious changes. Central to all strains of Bidayuh Christianity in the area is the need to cultivate ongoing relationships with God, Jesus, and other tutelary beings, while avoiding the potentially damaging wiles of Satan. However, unlike the old spirits, with whom horizontal relations of reciprocity were ritually managed, these Christian figures are understood to be immensely powerful beings-absolutes of good and evil who cannot be bargained with. Neither can they be manipulated or tricked because they can see what lies within people's hearts in a way that no human or gawai spirit can.

This awareness of relating to invisible yet omniscient presences has important implications for Bidayuh Christian morality. The arrival of God, Jesus, and others, I suggest, has given rise to new, distinctive types of relations, which I describe as "vertical" - in the sense of being dyadic and closed off to "horizontal" scrutiny or compulsion rather than simply hierarchical. Christians may seek advice from prayer leaders or discuss religious matters with their peers, but what transpires between them and the Divine is ultimately a private matter. Unlike the old spirits, however, Christian personages don't often leave explicit signs or messages for humans telling them what is "proper" (patut). Consequently, when participating in such vertical relations, many Christians have learned to become reflexive individual selves (Mauss [1938] 1985) who constantly strive to regulate their own behavior in accordance with what they understand of God, Jesus, Satan, and others. In effect, I argue, such relations amplify the importance of the autonomous moral core that lies at the heart of persons while augmenting the individualist impulses associated with it. To his neighbors, Daneh was not only an independent moral agent but also an individual Christian in a relationship with God. Consequently, they could criticize his visible actions but they would not presume to know (as God did) what he was like inside nor predict his postmortem fate. "Asi pu'an (who knows)?" they would ask rhetorically of both issues.

In its own alcohol-soaked way, Daneh's story illustrates the ongoing and often problematic dynamic between horizontal and vertical relations and the in/dividual impulses that they generate in contemporary Bidayuh life. Although the latter pull people in different directions, they are not incommensurate nor do they give rise to opposing states of being. Instead, to follow Geddes' analytical tack, I suggest that they are held in tenuous suspension within a single model of moral personhood, seguing in and out of prominence in accordance with particular situations over time. In the process, they variously foreground or suppress the different kinds of relations that are held to constitute Christian Bidayuh persons. These intersections became especially clear and problematic over the course of Daneh's life, which involved a constant tug-of-war-undertaken mainly by his peers-between his horizontal obligations and moral individuality. Conversely, his demise highlighted his personal, private vertical link to God, which had previously remained neglected. Removed in death from his horizontal bonds, Daneh was now an individual Christian in a dyadic relationship with God (and possibly Satan). And it was this recognition, I argue, that left the other villagers so agnostic about his ultimate fate: it simply lay beyond their remit and apprehension.

This brings us to a final feature of Daneh's story. In many ways, my interlocutors were not just agnostic about his final destiny but fundamentally disinterested in it. Their priority was the well-being of his bereaved relatives, and I was often 
cautioned against asking or saying too much about him when one of them was around. I found this emphasis on the well-being of the bereaved recurring throughout my fieldwork, regardless of who the deceased was. The next section examines why this was so, shifting the article's focus from the relations that constitute persons in life to the fate of those relations in death.

\section{Entering Jesus' village and other soteriological matters}

My acquaintances' reticence about postmortem fates betrays the intriguing fact that despite its centrality to Christian temporality (Robbins 2007), the afterlife is of minimal interest to them. Everybody agrees that there exists a place called Heaven (sorga)_-sometimes called Jesus' village (rais) — in which life is comfortable and beyond suffering, and in which those who "follow" Christianity are likely to end up. However, there is scant talk of alternatives. Hell is a shadowy and distant concept: although a notion of it exists in Bidayuh ethno-theology, ${ }^{4}$ it does not loom in people's awareness as a place of punishment. And although Purgatory has been incorporated into the vernacular catechism, it does not feature in many Catholics' knowledge or practices.

Unlike some millenarian forms of Christianity in which "people are forever pitched forward, placing their best attention on the future" (Robbins 2004: 164), then, much Bidayuh Christianity is not shaped primarily by fears, expectations and hopes for the afterlife. Indeed, heaven and hell can hardly be described as strong moral (dis)incentives that guide my acquaintances' this-worldly relations and behavior. A key reason for this, I argue, is that the Anglican, Catholic, and SIB churches all place great if varying emphasis on manifesting Christian precepts in the here and now, among one's kin and neighbors. From this perspective, getting to heaven is not the motivation for leading a good Christian life, but an upshot of "doing" (ndai) Christianity properly on earth. Individual persons may form the units of salvation (Robbins 2004: 293), but it is largely through their relations with others-that is, their horizontal investments in this world - that their lives and deaths as Christians are reckoned.

This is particularly true of Anglicanism and Catholicism, which embed their congregations firmly amid the living community on the basis that the best way to honor the dyadic bond between individuals and God is to act in and on the world. This injunction is reiterated during Anglican and Catholic prayer services, in which attendees are asked to pray for everything from faraway relatives to peace in the Middle East. Prayer gatherings are also regularly convened for specific ends: to bless a student starting college or a newly fixed car, to mark a birthday, or aid someone's recovery. Indeed, their occurrence is pivotal to many people's experiences of Christianity: involving large communal meals and hours of convivial conversation, they are relished for the sense of togetherness and feeling of rami (raucous, crowded, enjoyable) that they generate. When celebratory versions of

4. Missionaries and local churches translate "hell" as sebayan: the place of souls, spirits, and other supernatural beings in the gawai life-world. However, sebayan has no moral connotations: it is neither punishment nor reward for one's deeds in life. 
these gatherings are suspended during Lent, churches urge their congregations to direct their energy into performing good deeds, such as giving food to the poor and visiting sick people.

The social embeddedness of Anglicanism and Catholicism is often thrown into relief during conversations about the evangelical SIB, which constitutes a small minority in the village and shares soteriological affinities with Pentecostal and charismatic churches worldwide. SIB services-which consist mainly of praise and worship, spontaneous prayer, and close Bible readings-are viewed with perplexity by the other Christians, many of whom find its stress on self-cultivation pointless given its lack of impact in the world. "All they do is talk, talk, talk, and read the Bible," complained a woman who had lodged with SIB students at university, while a Catholic man grumbled, "the problem with SIBs is that they keep thinking about the end of the world. They distance themselves from it, not like us Catholics who do things [here he switched to English] in context"-that is, in the world. To be fair, however, these comments glossed over the fact that despite privileging their vertical relationship with God and the Holy Spirit and the prospect of individual salvation, SIBs also take their horizontal bonds in the community very seriously. What distinguishes them from the members of the two older churches is where they draw the line between dividual and individual priorities. While they are studiously good neighbors and willingly partake of parties and communal meals, for example, SIBs generally shun village discos, gambling sessions, and excessive drinking, which they construe as detrimental to their spiritual health, vertical relations, and individual responsibilities.

Put differently, Anglicans, Catholics, and SIBs all share a desire to fulfill their vertical obligations to God by nurturing their horizontal bonds in the present. The disparities between them are thus less of type than of degree, the key differential being which impulses they choose to prioritize and when. By and large, such predicaments are subsumed by a form of everyday Christianity that is characterized by its this-worldly commitments rather than its transcendental leanings. This, I suggest, partially accounts for my acquaintances' lack of interest in matters of the afterlife. However, their indifference also reflects a second distinct facet of Bidayuh Christianity: the fact that death marks the point at which the impulses that pull at persons in life cease their interplay and come apart to create individuals and communities.

\section{Death and the production of in/dividuals}

During fieldwork, I became familiar with a local adage: "When there is a wedding in the village, only those with invitations go. When there is a death, everybody goes." Notionally, death is an occasion that draws together the entire community and (in an unwittingly Durkheimian turn) makes it visible and real to its attendees. Such was the opinion of the people who regularly ushered me to the unusual number of postmortem prayer gatherings that dotted my early fieldwork. If you really want to study our culture, they said, come and join the prayers-you'll learn all about this village and our adat (way of life) there.

The notion that "death rituals tell us who we are" (Schiller 1997: 20) and serves as nodal points for collective sentiment and solidarity has been documented 
throughout Borneo-notably by Robert Hertz in his seminal essay on the socially regenerative nature of death (Hertz [1907] 1960; see also Couderc and Sillander 2012; Metcalf [1982] 1991; Schiller 1997). Strikingly, however, unlike the indigenous rituals studied by these scholars, pre-Christian Bidayuh mortuary practices were not especially communal in nature or orientation. Instead, I would argue that the intense sense of communitas that infuses contemporary Bidayuh experiences of death is relatively new, having been fostered in large part by conversion to Christianity. To appreciate the contrast, we need to look briefly at bereavement in the pre-Christian past.

As my acquaintances recollected, death in the old days was a hasty and fearful affair. When a person died, the body would lie at home for a couple of days before being wrapped in a mat and buried in an unmarked grave or left to rot in the jungle. Each death would warrant the imposition of three to four days' patang, or prohibition, on work (such as farming and house-building) and movement in and out of the affected longhouse. Adults could move about but children were locked up at home; my interlocutors remembered keeping very quiet and peeking out through cracks in the door while the body was still in the village. There were two reasons for these restrictions. First, death was and is seen as a dangerous, "hot" (păras) occurrence that upset the normal "coolness" of the community, making it vulnerable to malicious spirits. Ritually sealing the longhouse from the jungle, mountain, and rivers-liminal realms inhabited by dangerous beings-would keep its inhabitants safe until coolness was restored. Second, it was generally accepted that the soul (simangi) of the deceased could wander about for several days, unaware of its body's demise. Inadvertently encountering this entity-or another supernatural being attracted by the "smell" of death-could cause "fright-illnesses" particularly threatening to those with weakly attached souls, such as children. Adults would thus visit the bereaved household but not linger or go near it otherwise for fear that the deceased's soul would follow them home-a possibility that people still dread today.

In sum, what my acquaintances remember about bereavement in the past was the way it disrupted the ebb and flow of village life and made them "all afraid." On this point, they assert that Christianity is "better" because it has "freed" them from past fears, enabling them to walk around without worrying about breaking a patang or meeting wandering spirits. To an extent these musings must be understood as part of an ongoing discourse of rupture that Anglicans, Catholics, and SIBs craft in varying ways (see Chua 2012: Chapter 5): villagers today still observe a truncated or improvised patang on work and movement following a death, ${ }^{5}$ and wandering souls remain very real fears. Nevertheless, their ruminations point to a fundamental change in how death is today experienced and construed. As I now explain, rather than stilling the horizontal interactions of village life through confinement and restriction, Christian postmortem practice enlivens them, explicitly drawing people together in rituals of support and solidarity while sacralizing a notion of a village community that acts together to manifest God's love in the world.

5. Villagers often stop work for a day, while relatives of the deceased try not to leave the village for twenty-four hours. 
Compared to the old days, postmortem rituals in Bidayuh Christianity are lengthy, elaborate matters. A death invariably sparks a rush of activity in the deceased's home: the body is washed, dressed, and laid under a shroud before the household altar, the kitchen is commandeered by a bevy of women who prepare sweet drinks and full meals for the expected waves of visitors, and relatives and neighbors swarm in and out bearing food, drink, and cash. In theory, everybody in the village-exceptions are made for the elderly and infirm, pregnant women, and young children-is expected to visit the bereaved household. (In practice most people juggle this obligation with their working hours and other responsibilities.) Guests begin arriving almost as soon as the death is announced but reach their peak during evening Christian prayer sessions: seven nights of rosary recitations for Catholics, four nights of prayers for Anglicans, and slightly fewer for SIBs (who don't observe the same fixed prescriptions). These occasions pack the house, with people crammed against each other on the floor and spilling into the outside seating area. Following a prayer session, everyone partakes of a large buffet-style meal-a standard fixture at all Christian events-then settles down to drink, gossip, or gamble for the rest of the night.

As this description suggests, Bidayuh wakes and funerals are marked by sociability and conviviality-as people put it, they are unequivocally rami occasions. Here, there is no hushed reverence or squeamishness about the dead body, but a familiar mixture of commensality, chatter, jokes, and debates. Even sitting there without participating or sleeping in a corner is valued, because the point of such affairs, my acquaintances constantly repeat, is to keep the bereaved family company: to ensure they are not alone and stop them feeling afraid (tǎru) of ghosts who might try to "disturb" (ngasau) them. Noise and light are critical to this highly sensory enterprise; spirits are generally understood to experience things in reverse, so that if a house is quiet and dark they will assume the opposite and try to enter. The upshot of all this is that postmortem gatherings are imbued with a resolute air of normalcy that is only broken at specific transitional points, such as when the coffin is borne out the door for burial. Attendees do talk about the deceased and fret about his or her kin but they also discuss the latest news, catch up with old friends, look through photographs, and pass round food and drink. Such behavior, I suggest, has the same "protective" quality that Catherine Allerton attributes to the Manggarai notion of ramé (2012: 560): it ushers the bereaved back to the routine of daily life, thus shielding them from dangerously hot experiences that could cause illness or soul-loss. Moreover, because death is known to generate fear and sadness throughout the community (as it did in the past), these banal interactions are simultaneously efforts to restore coolness to the entire village.

In one respect, then, Christians attend wakes and funerals because they enjoy them; indeed, I was often asked at such events if I was having fun. But their participation in such postmortem proceedings also reflects a deep-seated awareness of their horizontal responsibilities to their fellow villagers and their dividual capacity to make things happen to and for them through those relations. Their presence is instrumental in preventing, not enacting, their transformation (cf. Allerton 2012) by mooring them firmly to social normalcy and the world of the living rather than leaving them susceptible to hot, ghostly, and potentially fatal forces from the realm of the dead. Strikingly, however, such affairs only became possible through the 
introduction of Christianity, the representatives of which taught their flock to combat fear and wandering spirits through prayer while also valorizing the collective forms through which to do so. In many ways, the injunction to "love thy neighbor" crystallizes in these nightly prayer sessions, at which villagers of all denominational stripes come together to support the bereaved family: a process that simultaneously makes the ideal community visible to itself and others. Central to this is the affective experience of collectively participating in meals, prayers, and ritual practices. My acquaintances often talk about how "following" prayers makes them feel better following a death. "My ashǔng [spirit, heart] felt sănang [at ease] when we began reciting the rosary," recalled one lady, while another described how she felt "cool" once the holy water sprinkled at the end of an Anglican session touched her forehead. SIBs, on the other hand, find solace in the act of communing with God through private, spontaneous prayer, but their experience is enriched through the sense of "fellowship" (English) that they derive from the presence of the other mourners.

Postmortem Christian prayers, however, serve a second vital function: that of "helping us to forget" (kambǔt) the deceased. For my acquaintances, merely thinking about (natǔng) someone is an agentive act, which has the effect of constituting and maintaining relations with them. To facilitate this, Bidayuhs often exchange small gifts or personal items, especially when they are about to be separated; these are effectively personal fragments that instantiate the horizontal bonds between them. In this capacity, remembering may be viewed as a dividual act that keeps relations alive and renders persons vulnerable to others. And it is here, I suggest, that remembering the dead can cause problems. Deceased Christians, it is broadly agreed, ought to end up in heaven but there is little consensus over when this happens or whether it is necessarily a one-way journey. The pre-Christian notion of the wandering soul remains very salient today, as does the possibility that it might reenter the orbit of human apprehension after its bearer's death. One way of causing this is to become consumed by the memory of the deceased, for to do so is to hold on to relations that should no longer exist, thereby preventing the dead person's spirit from properly leaving the society of the living.

In addition to keeping the soul in a place where it shouldn't be, constantly remembering the dead can damage the health and spirit of the bereaved. After her husband's sudden demise, my close elderly acquaintance fell into a deep depression lasting many months. She couldn't stop thinking about him, she said, and she could feel his spirit coming and going through the door of their house. Concerned about her failing health and distress, her children organized several extra prayer sessions-including one with visiting Catholic priests from town-in order to "help her forget." They also held prayers at the farm hut two hours' walk from the village where she and her husband often stayed, saying that this would help them to forget and feel less fear and sadness when they went out planting. This was well-attended by friends and relatives, who saw it as an extension of the previous few weeks' postmortem rituals.

Why do my acquaintances draw a causal link between Christian prayers and the capacity to forget, which after all does not feature in the vernacular liturgy or official teaching? A chief reason, I suggest, is that such rituals help to enact a separation between the dead and the living by creating an individual out of the deceased and a 
community out of those left behind. Although Anglican, Catholic, and SIB prayers all refer to the deceased as a "sibling" (saudara/madis), the postmortem liturgy, prayers, and sermons revolve around his or her deliverance from this world into a new life with God. This transformation is visually implied by the practice of removing or turning to the wall all photographs of the deceased in the bereaved house, leaving only a framed photograph by the corpse. This gesture arguably instantiates the understanding that this is the time when dead persons are disembedded from their horizontal relations and encompassed and redefined by their vertical relations with God. And although these persons are later integrated into a new collective unit-God's heavenly household-they continue in the long run to take the form of individuals from the perspective of the living. ${ }^{6}$ Their identity as such is literally cemented by the erection of permanent markers at their graves, notably tombstones bearing their name and photograph. Both the Anglican and Catholic churches also hold prayer sessions for individuals forty days, a hundred days, and a year after their death; thereafter, graves are visited and cleaned at least once a year on All Souls' Day, when Christians are exhorted to pray for the departed.

In a curious way, then, "forgetting" the deceased entails a specific, church-sanctioned form of memorialization: one that fixes the dead person's identity (as viewed by the living) as a detached individual rather than obliterating it. What my acquaintances seek to forget is not the person per se, but the horizontal relations that previously embedded the person in the living community. Put differently, it is at the point of death that the shifting dividual and individual impulses that make up personhood in life are pulled and kept apart. This effectively transforms the deceased into a new person: removed from the dividual influence of the living community, he or she is now turned into a bounded individual more closely resembling the EuroAmerican stereotype. This process is complemented and arguably superseded by the concomitant reassertion of the horizontal bonds from which the deceased has been released. For most of my acquaintances, postmortem rituals invariably start and end with "us" (kieh), the living community, the centrality of which is reflected in the themes of communal well-being, mutual support, and neighborly love that remain so prominent throughout the postmortem proceedings. In essence, I suggest, these events are occasions on which they can see and feel themselves acting as an ideal Christian village community. But crucially, and in contrast to the forms of cooperation described by Geddes, this community is valued and enshrined as an end in itself: as a locus of Christian practice and fellowship that is inherently worth nurturing.

\section{Conclusion}

To an extent, the missionaries whose words opened this article were correct to pinpoint the emergence of a kind of individualism among Bidayuh converts. Postmortem Christian prayers and rituals can indeed produce specific individuals: "sole

6. Although their incorporation into this household does entangle them in new horizontal relations with their heavenly brethren, this is, as discussed earlier, of little consequence to living Christians. 
unit[s] of divine judgment" (Robbins 2004: 293) who are vertically bound in death to God but not the living community. In some contexts, this soteriological eventuality has become the very framework of Christianity, generating "unrelentingly individualist" (293) priorities, practices, and temporal orientations. But in other settings, as Aparecida Vilaça also found among the Wari' (2011: 256), ideal images of the afterlife may not map straightforwardly onto the realities of the present. Bidayuh Christians may acknowledge the prospect of becoming a godly individual in death, but they do not therefore mold their daily lives around it. On the contrary, their disinterest in the afterlife arguably reflects their view of it as a vertical realm best left to God and the deceased. What matters to them as living Christians is how they manifest those vertical bonds in the here and now through their horizontal investments in the world, notably the ideal community.

In pointing this out, my objective is not to counter the classic narrative of Christianity as an individuating force (e.g., Dumont 1965; Mauss [1938] 1985; Keane 2007; Robbins 2004) by showing how it creates dividuals of various kinds (e.g. Vilaça 2011; Werbner 2011) or how individuals may be construed as dividuals (Mosko 2010: 219) or vice versa. Neither is it to downplay the ethnographic specificity of Bidayuhs' moral maneuvers and dilemmas by treating them as particular manifestations of what is arguably a more general truth: that "in all cultures . . . there exist both individual and dividual modalities or aspects of personhood" (LiPuma 1998: 56). Instead, my aim has been to open the possibility of exploring questions of in/dividualism beyond personhood, on which much of the anthropological debate has hitherto centered. As I have tried to show, neither indigenous Bidayuh sociality nor Christian life can be described as purely relational or individualist. Instead, both are shaped by intrinsically relational in/dividualistic values and motivations that are culturally elaborated in diverse ways (e.g., membership of the ideal community, the simangi, "loving thy neighbor," and the godly self). These impulses are not associated with distinct forms of personhood, but coexist in various permutations that dwell within and crosscut persons. In a Christian milieu where individuals are only firmly established as such after their death, my acquaintances do not find themselves torn between being or becoming different kinds of persons. Rather, as horizontally and vertically bound yet morally autonomous persons, the challenge that they face is how to juggle all these relations and the impulses to which they give rise.

It is here, I suggest, that analytical rewards may be reaped from the adoption of a processual perspective. Rather than pinpointing persons as dividual or individual entities, a processual approach traces the interplay of in/dividualist tendencies on different scales and temporalities-not only in day-to-day sociality but also in the rhythm of Christian rituals, personal biographies, and chronological time. Such a perspective reveals how persons can take on different social forms and identities at different times (Strathern 1988: 176) depending on the particular configuration of relations, interactions, and motivations at work. For example, although Daneh appeared chiefly as a horizontally constituted villager when scolded by his peers, he nevertheless retained his individual moral autonomy and responsibilities as a selfregulating Christian "vertically" related to God: these features remained part of his person, becoming more or less visible or compelling at other times. It is only by taking a long view of his life and death rather than focusing on singular incidents 
that we can discern the constant push and pull of the different but not incommensurate impulses with which he and his peers had to deal.

A processual approach also provides a useful vantage point on the question of denominational pluralism. While diverse, the current anthropology of Christianity has paid relatively little attention to heterogeneity within Christian communities $^{7}$ - to interdenominational relations, for example, or to conflict within the same church. For the moment, the literature remains densely populated by ethnographies of relatively bounded, mostly Protestant "cultures" structured around single churches or denominations. This article, however, highlights the importance of attending to Christianity's own multiplicity by showing how members of all three congregations in my adoptive village grapple with the same combination of in/ dividualist concerns in their lives. Depending on where they position themselves along the horizontal and vertical relational axes, their choices may momentarily foreground their dividual or individual identities-but at the end of the day, as they themselves insist, they are all "the same" as Christians and village residents. Their ruminations underscore the analytical importance-which Geddes demonstrated through his ethnography-of distinguishing between ideals, motivations, and effects when exploring the multifarious manifestations of Christianity and other religious complexes in diverse settings.

Finally, a recursive observation: Throughout this article, I have used the terms "dividual" and "individual" as rough comparative analogues for clusters of ideas and practices that have no collective name in my acquaintances' lives. But of course, anthropologists are not the only ones to think with and through heuristic devices: so too do the people with whom we work. In this regard, it is curiously apt that anthropologists have drawn on and often been complicit in the very imaginative project with which missionaries and Christian Bidayuhs have grappled: a historically particular Euro-American ideology of individualism that has made its own jagged, erratic trajectories across space and time. A more explicit recognition of this fact, I suggest, may help to enrich ongoing in/dividualism debates, which have for the most part revolved around non-Western alterity and difference-a point noted by Mosko (2010), who sought in his own-hotly disputed-way to rectify this bias. Although the jury is still out on his claims, I suggest that anthropologists may derive analytical mileage from the spirit in which he formulated them: by applying the same critical lens to Western individualism as we have to non-Western dividualism, rather than starting with an a priori bifurcation (heuristic or otherwise) between Western and non-Western socialities (see also Bloch 2011). Indeed, as anthropologists strive to take the very substance and forms of Christianity seriously, the time may now be ripe to interrogate the affinities between "us" and "them," "the West" and "the rest" and anthropology and other projects of representation-to the extent, perhaps, of collapsing such distinctions. But that is fodder for another paper.

7. Exceptions include Barker 2003; Chua 2012; Eriksen 2012; Hemer 2011; Jebens 2011; McDonald 2001; McDougall 2009; Ryle 2010. 


\section{Acknowledgments}

Fieldwork was supported by the William Wyse, Evans, Smuts Memorial, and the Bartle Frere Memorial Funds at the University of Cambridge and a Royal Anthropological Institute Horniman/Sutasoma Award. I am grateful to Jon Bialecki and Girish Daswani for including me in this special section and to Giovanni da Col and my anonymous reviewers for helping to rescue this piece from the post-maternityleave fog in which it was written.

\section{References}

Allerton, Catherine. 2012. 'Making guests, making 'liveliness': The transformative substances and sounds of Manggarai hospitality." Special issue, Journal of the Royal Anthropological Institute (n.s.) 18: S49-S62.

Barker, John. 2003. "Christian bodies: Dialectics of sickness and salvation among the Maisin of Papua New Guinea." Journal of Religious History 27 (3): 272-92.

Bloch, Maurice. 2011. “The blob.” Anthropology of this Century 1, May 2011. http://aotcpress. com/articles/blob/.

Busby, Cecilia. 1997. "Permeable and partible persons: A comparative analysis of gender and body in South India and Melanesia." Journal of the Royal Anthropological Institute (n.s.) 3: 261-78.

Chua, Liana. 2009. "What's in a (big) name? The art and agency of a Bornean photographic collection." Anthropological Forum 19 (1): 33-52.

- 2012. The Christianity of culture: Conversion, ethnic citizenship and the matter of religion in Malaysian Borneo. New York: Palgrave Macmillan.

Couderc, Pascal, and Kenneth Sillander, eds. 2012. Ancestors in Borneo societies: Death, transformation, and social immortality. Copenhagen: NIAS Press.

Daswani, Girish. 2011. “(In-)Dividual Pentecostals in Ghana.” Journal of Religion in Africa 41 (3): 256-79.

Dumont, Louis. 1965. "The modern conception of the individual: Notes on its genesis and that of concomitant institutions." Contributions to Indian Sociology 8: 31-61.

Eriksen, Annelin. 2012. "The pastor and the prophetess: An analysis of gender and Christianity in Vanuatu." Journal of the Royal Anthropological Institute (n.s.) 18: 103-22.

Geddes, William. 1954. The Land Dayaks of Sarawak: A report on a social economic survey of the Land Dayaks of Sarawak presented to the Colonial Social Science Research Council. London: HM Stationery Office.

—. 1957. Nine Dayak nights. London: Oxford University Press.

Gibson, Thomas, and Kenneth Sillander, eds. 2011. Anarchic solidarity: Autonomy, egalitarianism and fellowship in Southeast Asia. New Haven, CT: Yale University Press.

Hemer, Susan R. 2011. "Local, regional and worldly interconnections: The Catholic and United Churches in Lihir, Papua New Guinea." The Asia Pacific Journal of Anthropology 12 (1): 60-73. 
Hertz, Robert. (1907) 1960. "A contribution to the study of the collective representation of death." In Death and the right hand, translated by Rodney and Claudia Needham. London: Cohen and West.

Howes, Peter H. H. 1960. "Why some of the best people aren’t Christian." Sarawak Museum Journal (9) 15: 488-95.

Jebens, Holger. 2011. "Beyond globalisation and localisation: Denominational pluralism in a Papua New Guinean village." The Asia Pacific Journal of Anthropology 12 (1): 91-110.

Keane, Webb. 2007. Christian moderns: Freedom and fetish in the mission encounter. Berkeley: University of California Press.

Keeler, Ward. 1987. Javanese shadow plays, Javanese selves. Princeton, NJ: Princeton University Press.

Lambek, Michael, and Andrew Strathern, eds. 1998. Bodies and persons: Comparative perspectives from Africa and Melanesia. Cambridge: Cambridge University Press.

Leach, Edmund. 1950. Social science research in Sarawak. London: H. M. Stationery Office.

LiPuma, Edward. 1998. "Modernity and forms of personhood in Melanesia." In Bodies and persons: Comparative perspectives from Africa and Melanesia, edited by Michael Lambek and Andrew Strathern, 53-79. Cambridge: Cambridge University Press.

Marriott, McKim. 1976. "Hindu transactions: Diversity without dualism." In Transaction and meaning, edited by Bruce Kapferer, 109-42. Philadelphia, PA: ISHI Publications.

Mauss, Marcel. (1938) 1985. "A category of the human mind: The notion of person, the notion of self." In The category of the person, edited by Michael Carrithers, Steven Collins, and Steven Lukes, 1-25. Cambridge: Cambridge University Press.

McDonald, Heather. 2001. Blood, bones and spirit: Aboriginal Christianity in an East Kimberley town. New York: Palgrave Macmillan.

McDougall, Debra. 2009. "Becoming sinless: Converting to Islam in the Christian Solomon Islands." American Anthropologist 111 (4): 480-91.

Metcalf, Peter. (1982) 1991. A Borneo journey into death: Berawan eschatology from its rituals. Kuala Lumpur: S. Abdul Majeed and Co.

Mosko, Mark. 2010. "Partible penitents: Dividual personhood and Christian practice in Melanesia and the West." Journal of the Royal Anthropological Institute (n.s.) 16: 215-40.

Robbins, Joel. 2004. Becoming sinners: Christianity and moral torment in a Papua New Guinea society. Berkeley: University of California Press.

2 2007. "Continuity thinking and the problem of Christian culture: Belief, time, and the anthropology of Christianity." Current Anthropology 48 (1): 5-38.

- 2010. "Melanesia, Christianity, and cultural change: A comment on Mosko's 'Partible penitents." Journal of the Royal Anthropological Institute (n.s.) 16: 241-43.

Ryle, Jacqueline. 2010. My God, my land: Interwoven paths of Christianity and tradition in Fiji. Farnham: Ashgate.

Sather, Clifford. 1996. “'All threads are white': Iban egalitarianism reconsidered.” In Origins, ancestry and alliance: Explorations in Austronesian ethnography, edited by James Fox and 
Clifford Sather, 73-112. Canberra: Department of Anthropology, Australian National University.

Schiller, Anne. 1997. Small sacrifices: Religious change and cultural identity among the Ngaju of Indonesia. Oxford: Oxford University Press.

Sidaway, David. 1969. "Influence of Christianity on Biatah-speaking Land Dayaks." Sarawak Museum Journal 17 (34/5): 139-52.

Strathern, Marilyn.1988. The gender of the gift. Berkeley: University of California Press.

Vilaça, Aparecida. 2011. "Dividuality in Amazonia: God, the devil and the constitution of personhood in Wari' Christianity." Journal of the Royal Anthropological Institute (n.s.) 17: $243-62$.

Werbner, Richard. 2011. Holy hustler, schism, and prophecy: Apostolic reformation in Botswana. Berkeley: University of California Press.

\section{Des relations horizontales et verticales: Regard sur l' "in/dividualisme" des Bidayus chrétiens}

Résumé : Cet article participe au débat sur la dividualité et l'individualité en proposant de réfléchir à un ensemble d'idées et de pratiques des Bidayuh, un groupe originaire de la partie Malaisienne de Borneo. Quand les Bidayuh commencèrent à se convertir au christianisme dans les années 50, certains missionnaires contrastèrent leur mode de vie en communauté et "l'individualisme" de la nouvelle religion. En mappuyant sur des ethnographies contemporaines et mes propres recherches, jébauche une description plus complexe, en montrant comment les socialités préchrétienne et chrétienne ont été définies par l'intersection changeante des forces "in/dividuelles" dérivant des relations "horizontales" et "verticales" dans lesquelles les personnes sont prises. En considérant les trajectoires tracées par ces forces et leurs croisement, de la vie à la mort et au delà, cet article tente de détacher les questions sur l'in/dividualisme de la notion de personne, tout en défendant la nécessité de prendre au sérieux les nuances et les affinités des différents types de christianisme et de socialités occidentales et non-occidentales.

Liana CHuA is Lecturer in Anthropology at Brunel University London. She works on Christianity, ethnic and cultural politics, resettlement and development in Sarawak, Malaysian Borneo, and has broader research interests in artifact-oriented theory, materiality, and indigenous museums.

Liana Chua

Division of Anthropology

Brunel University London

Uxbridge, UB8 3PH

United Kingdom

liana.chua@cantab.net 